\title{
JURNAL TESLA
}

\section{EDITORIAL}

Salam kepada saudara sekalian, semoga di tahun 2019 ini dapat menjadi awal tahun yang baik untuk saudara sekalian. Terima kasih kepada bapak/ibu penulis artikel yang dengan sangat antusias dan mengirimkan artikel tepat waktu penerbitan pada bulan Maret 2019. Kali ini terkumpulnya artikel dari berbagai latar belakang penulis, dari praktisi, mahasiswa, hingga pengajar di sejumlah universitas di Jakarta \& di Bandung. Diharapkan Jurnal TESLA juga dapat dibaca tidak hanya bagi komunitas di Jakarta namun bisa di luar Jawa. Semoga Artikel di dalam Jurnal TESLA ini dapat bermanfaat untuk bagi para pembaca bapak/ibu komunitas di Jakarta maupun di luar Jakarta.

Jakarta, Maret 2019

Redaksi Jurnal TESLA 